\title{
Structure-Based Engineering of Phanerochaete chrysosporium Alcohol Oxidase for Enhanced Oxidative Power toward Glycerol
}

Quoc-Thai Nguyen, ${ }^{\dagger, \downarrow, \S}$ Elvira Romero, ${ }^{\dagger}$ Willem P. Dijkman, ${ }^{\dagger, \#}$ Suzan Pantaroto de Vasconcellos, ${ }^{\dagger, \perp}$

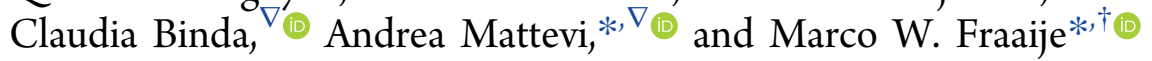

${ }^{\dagger}$ Molecular Enzymology Group, Groningen Biomolecular Sciences and Biotechnology Institute, University of Groningen, Nijenborgh 4, 9747 AG Groningen, The Netherlands

${ }^{\ddagger}$ Scuola Universitaria Superiore IUSS Pavia, Piazza della Vittoria 15, 27100 Pavia, Italy

${ }^{\S}$ Faculty of Pharmacy, University of Medicine and Pharmacy at Ho Chi Minh City, 41 Dinh Tien Hoang Street, Ben Nghe Ward, District 1, Ho Chi Minh City, Vietnam

${ }^{\perp}$ Department of Biological Science, Federal University of São Paulo (UNIFESP), Diadema, SP 09913-030, Brazil

${ }^{\nabla}$ Department of Biology and Biotechnology, University of Pavia, Via Ferrata 1, 27100 Pavia, Italy

\section{Supporting Information}

ABSTRACT: Glycerol is a major byproduct of biodiesel production, and enzymes that oxidize this compound have been long sought after. The recently described alcohol oxidase from the white-rot basidiomycete Phanerochaete chrysosporium (PcAOX) was reported to feature very mild activity on glycerol. Here, we describe the comprehensive structural and biochemical characterization of this enzyme. PcAOX was expressed in Escherichia coli in high yields and displayed high thermostability. Steady-state kinetics revealed that PcAOX is highly active toward methanol, ethanol, and 1-propanol $\left(k_{\text {cat }}=\right.$ 18,19 , and $11 \mathrm{~s}^{-1}$, respectively), but showed very limited activity toward glycerol $\left(k_{\mathrm{obs}}=0.2 \mathrm{~s}^{-1}\right.$ at $2 \mathrm{M}$ substrate $)$. The crystal structure of the homo-octameric PcAOX was determined at a resolution of $2.6 \AA$. The catalytic center is a remarkable solvent-inaccessible cavity located at the re side of the flavin cofactor. Its small size explains the observed preference for methanol and ethanol as best substrates. These findings led us to design several cavity-enlarging mutants with significantly improved activity toward glycerol. Among them, the F101S variant had a high $k_{\text {cat }}$ value of $3 \mathrm{~s}^{-1}$, retaining a high degree of thermostability. The crystal structure of F101S PcAOX was solved, confirming the site of mutation and the larger substrate-binding pocket. Our data demonstrate that PcAOX is a very promising enzyme for glycerol biotransformation.
$\mathrm{F}$ lavin-containing oxidases have gained considerable attention and popularity in biotechnological applications, because of their ability to catalyze oxidations of alcohols and amines with exquisite chemoselectivies, regioselectivies, and/or enantioselectivies. ${ }^{1-4}$ The interest for these biocatalysts stems from their dependence on molecular oxygen - an inexpensive and environmentally benign oxidant-as an electron acceptor, which is typically reduced to hydrogen peroxide $\left(\mathrm{H}_{2} \mathrm{O}_{2}\right)$. Furthermore, the equilibrium of the reactions catalyzed by flavin-dependent oxidases is shifted toward the oxidation of the organic substrate, while the reduction is often favored in the equivalent redox reactions catalyzed by dehydrogenases. ${ }^{5}$ The most well-known examples of oxidase biocatalysts include glucose oxidase, ${ }^{6}$ D-amino acid oxidase, ${ }^{7}$ monoamine oxidase, ${ }^{8}$ and cholesterol oxidase, ${ }^{9}$ which have been widely used for decades in bioanalytical, agrochemical, and pharmaceutical applications.

Alcohol oxidases (AOX, EC 1.1.3.13), also known as methanol oxidases, belong to the glucose-methanol-choline
(GMC) oxidoreductase superfamily and contain a noncovalently bound FAD cofactor. ${ }^{10-12}$ AOXs from methylotrophic yeasts catalyze the oxidation of methanol, yielding formaldehyde and $\mathrm{H}_{2} \mathrm{O}_{2}$ in specialized organelles, the peroxisomes, where the latter product can be decomposed by co-compartmentalized catalase. ${ }^{13}$ AOX from Gloeophyllum trabeum and presumably from other wood-degrading basidiomycetes are instead associated with periplasmic and external membranous structures. ${ }^{14}$ This distribution supports the proposed role of basidiomycete AOXs in providing $\mathrm{H}_{2} \mathrm{O}_{2}$ for wood decay, at the expense of the methanol resulting from lignin demethoxylation. ${ }^{14}$ In addition to the physiological substrate methanol, AOXs can typically oxidize also short aliphatic primary alcohols of up to four carbons. Although being discovered 50 years ago, the first AOX structure was

Received: August 31, 2018

Revised: September 30, 2018

Published: October 1, 2018 
elucidated only in 2016 [AOX from Pichia pastoris, reassigned to the genus Komagataella (PpAOX1).$^{15,16}$

Recently, a novel AOX from the white-rot basidiomycete Phanerochaete chrysosporium was identified and isolated (PcAOX; GenBank: HG425201, UniProtKB/TrEMBL: T2M2J4). ${ }^{17}$ The corresponding gene does not include the C-terminal sequence involved in targeting yeast AOXs to peroxisomes, ${ }^{18}$ as expected for basidiomycete AOXs (see above). The reported substrate profiling data for PcAOX indicated that the enzyme accepts aliphatic primary alcohols of up to five carbon atoms. Interestingly, glycerol, which is a polyol currently accumulated as an excessive side-stream of biodiesel manufacture, was described as a (poor) substrate for PcAOX. ${ }^{17}$ This fact suggested that PcAOX has a great potential in biotechnology and prompted us to further investigate this oxidase.

In this context, the goal of our present study was 3-fold. First, we established an extremely effective recombinant expression system for producing PcAOX in Escherichia coli (rather than using homologous expression or yeast). This enabled a more-detailed characterization of the newly identified PcAOX and explorative studies of this enzyme as an industrial biocatalyst. Second, we determined the X-ray structure of PcAOX, which represents the second known AOX structure and adds insights into the structural features and catalytic mechanism of this class of enzymes. Finally, based on the structural information, we mutated a few key residues within the active site of PcAOX, converting this enzyme to a better glycerol oxidase, which is the ultimate goal of this project.

\section{MATERIALS AND METHODS}

Cloning of Wild-Type AOX. The open reading frame for AOX from P. chrysosporium (GenBank: HG425201, UniProtKB/TrEMBL: T2M2J4) was purchased from GenScript (Piscataway, NJ, USA) with optimized codons for protein expression in E. coli. The aoxl gene was amplified from the delivered plasmid using Phusion High-Fidelity DNA polymerase (Thermo Scientific) and the corresponding pair of primers shown in Table S1 in the Supporting Information. The purified PCR products (100-200 ng) were incubated with $0.5 \mathrm{U}$ Taq polymerase (Roche) and $0.75 \mathrm{mM} \mathrm{dATP}$ at $72{ }^{\circ} \mathrm{C}$ for $15 \mathrm{~min}$ to introduce the $3^{\prime}$-A overhangs. The resulting insert DNA fragments were ligated into the $\mathrm{pET}$-SUMO vector, according to the instruction manual of the Champion $\mathrm{pET}$ SUMO expression system (Invitrogen). In the pET-SUMO-AOX construct, the gene encoding for wild-type PcAOX is fused to the C-terminus of SUMO. ${ }^{19}$ SUMO carries a His-tag at the N-terminus.

Generation of AOX Mutants. The construction of the PcAOX mutants F101S, F101N, M103S, and M103N was done by using the QuikChange mutagenesis method with the corresponding pairs of primers shown in Table $S 1$ in the Supporting Information. The pET-SUMO-AOX plasmid was used as a template. All mutations were confirmed by sequencing.

Protein Expression and Purification. Transformed E. coli BL21(DE3) were grown in Terrific Broth containing 50 $\mu \mathrm{g} / \mathrm{mL}$ kanamycin and $1 \%(\mathrm{w} / \mathrm{v})$ glucose at $37{ }^{\circ} \mathrm{C}$. Protein expression was induced when the cultures reached $\mathrm{OD}_{600} \approx$ $0.7-0.8$ by adding $1 \mathrm{mM}$ isopropyl $\beta$-D-1-thiogalactopyranoside. Next, the cells were incubated at $24{ }^{\circ} \mathrm{C}$ until late stationary phase and then harvested by centrifugation at $4600 \mathrm{~g}$ for $10 \mathrm{~min}$ (Beckman-Coulter JA-10 rotor, $4{ }^{\circ} \mathrm{C}$ ). The resulting cell pellet was stored at $-20{ }^{\circ} \mathrm{C}$.

Cells were resuspended in lysis buffer $(50 \mathrm{mM}$ potassium phosphate $\mathrm{pH} 7.8,400 \mathrm{mM} \mathrm{NaCl}, 100 \mathrm{mM} \mathrm{KCl}, 20 \mathrm{mM}$ imidazole, $100 \mu \mathrm{M} \mathrm{FAD)}$ ) and mechanically disrupted by sonication using a VCX130 Vibra-Cell (Sonics \& Materials, Inc., Newtown, CT, USA) at $4{ }^{\circ} \mathrm{C}(5 \mathrm{~s}$ on, $10 \mathrm{~s}$ off, $70 \%$ amplitude, total of $5 \mathrm{~min}$ ). After the removal of cellular debris by centrifugation $(20000 \mathrm{~g}$, Beckman-Coulter JA-25.5 rotor, 4 ${ }^{\circ} \mathrm{C}, 45 \mathrm{~min}$ ), the supernatant was loaded onto a $5 \mathrm{~mL}$ HisTrap HP column (GE Healthcare) pre-equilibrated using the lysis buffer. The elution of the recombinant enzyme fused to the His-SUMO tag was performed using a 20-500 mM imidazole gradient. Fractions containing the pure enzyme as indicated by SDS-PAGE were pooled and then desalted and concentrated using a $30-\mathrm{kDa}$ MWCO Amicon (Millipore) centrifugal filter unit and potassium phosphate buffer $(50 \mathrm{mM}, \mathrm{pH} 7.5)$. To obtain the nonfused PcAOX, the His-SUMO tag was cleaved by incubating with $10 \%(\mathrm{~mol} / \mathrm{mol})$ SUMO protease (Invitrogen) overnight at $4{ }^{\circ} \mathrm{C}$ in lysis buffer supplemented with $1 \mathrm{M}$ urea. Subsequently, the nonfused PcAOX was purified from the cleavage mixture via gel permeation, using a Superdex 200 10/300 GL (GE Healthcare) column and 10 $\mathrm{mM}$ Tris- $\mathrm{HCl} \mathrm{pH} 7.5$ buffer with $100 \mathrm{mM} \mathrm{NaCl}$ prior to crystallization experiments. Mutant proteins were expressed and purified as the wild-type enzyme.

Biochemical Characterization. Purified PcAOX, either untagged or SUMO-tagged, wild-type or mutant, proteins were purified as fully FAD-bound holoenzymes and there was no need to supplement FAD during purification, indicating tight binding of the cofactor. The UV-vis spectrum of wild-type HisSUMO-PcAOX was recorded from $250 \mathrm{~nm}$ to $650 \mathrm{~nm}$ in 50 $\mathrm{mM}$ Tris- $\mathrm{HCl} \mathrm{pH} 7.0$ before and after addition of $0.1 \%(\mathrm{w} / \mathrm{v})$ sodium dodecyl sulfate (SDS). The extinction coefficient of PcAOX was determined based on that of free FAD, as described previously. ${ }^{20}$

The $\mathrm{pH}$ optimum for the wild-type enzyme activity was determined based on dioxygen consumption rates, using methanol as a substrate. The reaction contains $40 \mathrm{mM}$ Britton-Robinson buffer at various $\mathrm{pH}$ values, ${ }^{21} 0.1 \mu \mathrm{M}$ enzyme, and $25 \mathrm{mM}$ methanol in a final volume of $1 \mathrm{~mL}$. Activities were monitored for $5 \mathrm{~min}$ at $23{ }^{\circ} \mathrm{C}$ using a Hansatech Oxygraph instrument (Hansatech Instruments Ltd., Norfolk, U.K.). Prior to the measurements, the zero dioxygen level was calibrated by complete reduction using sodium dithionite.

PcAOX thermostability was determined based on the apparent melting temperature of the enzyme using the ThermoFAD protocol as previously described, ${ }^{22}$ with a MiniOpticon real-time PCR detection system and 48-well RT-PCR plates (Biorad Laboratories, Hercules, CA, USA). Each well has a final volume of $20 \mu \mathrm{L}$ containing $2.0 \mu \mathrm{L}$ of 100 $\mu \mathrm{M}$ AOX stock (in $50 \mathrm{mM}$ potassium phosphate $\mathrm{pH} 7.5$ ) diluted in the tested buffers (in duplicate). In the case of the F101S PcAOX variant, the long-term stability was investigated by incubating the enzyme $(32 \mu \mathrm{M})$ in $100 \mathrm{mM}$ potassium phosphate $\mathrm{pH} 7.5$ and $25^{\circ} \mathrm{C}$ for 7 days $(200 \mu \mathrm{L}$, final volume). An aliquot $(5 \mu \mathrm{L})$ of the enzyme solution was taken at several time points to determine enzyme activity on glycerol (2 M) using a horseradish peroxidase (HRP)-coupled assay in $50 \mathrm{mM}$ potassium phosphate $\mathrm{pH} 7.5$ (100 $\mu \mathrm{L}$, final volume). $\mathrm{H}_{2} \mathrm{O}_{2}$ generated by the oxidase $(1 \mu \mathrm{M})$ is used by HRP $(40 \mathrm{U} / \mathrm{mL}$, Sigma) to catalyze the oxidative coupling reaction of 4- 
aminoantipyrine $(0.1 \mathrm{mM})$ and 3,5-dichloro-2-hydroxybenzenesulfonic acid $(1 \mathrm{mM})$. This assay results in the formation of a pink to purple quinoid product that was monitored at 515 $\mathrm{nm}\left(\varepsilon_{515}=26 \mathrm{mM}^{-1} \mathrm{~cm}^{-1}\right)$, using a Cary 100 Bio UV-visible spectrophotometer (Varian, Inc., USA) at $25{ }^{\circ} \mathrm{C} .{ }^{23}$ This assay was also used to study the influence of $\mathrm{NaCl}(0.025-1.0 \mathrm{M}$ $\mathrm{NaCl})$ on the activity on glycerol $(2 \mathrm{M})$ for the F101S PcAOX variant $(1 \mu \mathrm{M})$ in $100 \mathrm{mM}$ potassium phosphate $(\mathrm{pH} 7.5)$.

To determine the apparent steady-state kinetics parameters, AOX $(40-0.5 \mu \mathrm{M})$ activity on various substrates was measured at $25{ }^{\circ} \mathrm{C}$ in $50 \mathrm{mM}$ potassium phosphate $\mathrm{pH} 7.5$ using the HRP-coupled assay.

Purpald Assay. F101S PcAOX (13 $\mu \mathrm{M})$ was reacted with glycerol $(205 \mathrm{mM})$ in $100 \mathrm{mM}$ potassium phosphate $\mathrm{pH} 7.5$ containing $2 \mathrm{mM}$ 1,4-dithiothreitol and $1014 \mathrm{U}$ catalase (Micrococcus lysodeikticus, Sigma-Aldrich), at $25{ }^{\circ} \mathrm{C}$ and 50 rpm (Innova 40 incubator shaker; $2 \mathrm{~mL}$ reactions in $20 \mathrm{~mL}$ vials). After $68 \mathrm{~h}$ of incubation, $200 \mu \mathrm{L}$ of the reactions were mixed with $200 \mu \mathrm{L}$ of Purpald (Sigma-Aldrich, $5 \mathrm{mg} / \mathrm{mL}$ in $0.5 \mathrm{~N} \mathrm{NaOH}$ ). Next, samples were incubated at $30^{\circ} \mathrm{C}$ and 700 rpm for $30 \mathrm{~min}$ (Eppendorf ThermoMixer C) and subsequently mixed with $600 \mu \mathrm{L}$ of water. Finally, $50 \mu \mathrm{L}$ of the resulting solutions were diluted with $950 \mu \mathrm{L}$ of water to record their absorbance spectrum. In parallel, the same procedure was performed for control reactions without F101S PcAOX, except that the last dilution (1:20) was not performed before measuring. Similarly, $200 \mu \mathrm{L}$ of $1 \mathrm{mM}$ glyceraldehyde, glycerol, and glyceric acid were reacted with $200 \mu \mathrm{L}$ of Purpald. Subsequently, these standard solutions were diluted with water (final concentration $=0.2 \mathrm{mM}, 1 \mathrm{~mL}$ ) just prior to recording their absorbance spectrum.

Protein Crystallization, X-ray Data Collection, and Structure Determination. The wild-type and F101S PcAOXs were crystallized using the sitting-drop vapor diffusion technique at $20{ }^{\circ} \mathrm{C}$ by mixing equal volumes of 9.3 $\mathrm{mg} / \mathrm{mL}$ enzyme (in $10 \mathrm{mM}$ Tris- $\mathrm{HCl} \mathrm{pH} 7.5,100 \mathrm{mM} \mathrm{NaCl}$, $66 \mu \mathrm{M} \mathrm{FAD})$ and mother liquor containing $14 \%(\mathrm{w} / \mathrm{v})$ PEG3350 and $0.2 \mathrm{M}$ potassium acetate. Prior to X-ray data collection, crystals were cryo-protected in solution containing 18\% (w/v) PEG3350, $0.2 \mathrm{M}$ potassium acetate, and 20\% (v/v) glycerol and were flash-cooled by plunging them into liquid nitrogen. X-ray diffraction (XRD) data to 2.5-2.6 $\AA$ were collected at the ID23-EH2 and ID29 beamlines of the European Synchrotron Radiation Facility in Grenoble, France (ESRF) and at the PXIII beamline of the Swiss Light Source (SLS) in Villigen, Switzerland. Image indexing, integration, and data scaling were processed with the Xds package ${ }^{24,25}$ and programs of the CCP4 suite. ${ }^{26}$ The diffraction images for the wild-type enzyme appeared strongly anisotropic, extending to 3.1, 2.6, and $2.4 \AA$ resolution in the direction of $a^{*}, b^{*}$, and $c^{*}$, respectively, which resulted in a high $R_{\text {sym }}$ value (see Table 1 ). The high-resolution shell cutoff was determined based on the correlation coefficient of half-datasets $\left(\mathrm{CC}_{1 / 2}\right)$ and visual inspection of the quality of the electron density map as previously described. ${ }^{27,28}$

The wild-type PcAOX structure was solved by molecular replacement using Phaser $^{29}$ and the coordinates of PpAOX1 [Protein Databank (PDB) ID: 5HSA], ${ }^{15}$ which shares 52\% sequence identity with PcAOX, as the search model devoid of all ligand and water molecules. Similarly, the F101S mutant structure was solved using the coordinates of the wild-type PcAOX. Manual model rebuilding and structure inspection were performed with Coot, ${ }^{30}$ whereas alternating cycles of
Table 1. Data Collection and Refinement Statistics

\begin{tabular}{|c|c|c|}
\hline PcAOX & wild-type & F101S \\
\hline PDB ID & $6 \mathrm{H} 3 \mathrm{G}$ & $6 \mathrm{H} 3 \mathrm{O}$ \\
\hline space group & $P 2_{1}$ & $P 2_{1}$ \\
\hline resolution $(\AA)$ & 2.60 & 2.50 \\
\hline \multicolumn{3}{|l|}{ unit-cell dimensions } \\
\hline$a(\AA)$ & 112.7 & 112.1 \\
\hline$b(\AA)$ & 204.0 & 203.6 \\
\hline$c(\AA)$ & 116.5 & 116.0 \\
\hline$R_{\text {sym }}^{a, b}(\%)$ & $13.3(109.2)$ & $14.4(65.7)$ \\
\hline completeness $^{b}(\%)$ & $97.8(97.8)$ & $98.5(96.8)$ \\
\hline unique reflections & 151989 & 170450 \\
\hline multiplicity $^{b}$ & $3.6(3.6)$ & $2.9(2.9)$ \\
\hline$I / \sigma^{b}$ & $6.9(0.9)$ & $6.3(1.4)$ \\
\hline $\mathrm{CC}_{1 / 2}^{b}$ & $0.99(0.39)$ & $0.98(0.49)$ \\
\hline \multicolumn{3}{|l|}{ number of atoms } \\
\hline protein & 40134 & 40654 \\
\hline $\mathrm{FAD}$ & $8 \times 53$ & $8 \times 53$ \\
\hline glycerol & $5 \times 6$ & $2 \times 6$ \\
\hline water & 578 & 695 \\
\hline average $B$ value for all atoms $\left(\AA^{2}\right)$ & 56.6 & 32.9 \\
\hline$R_{\text {cryst }}^{b, c}(\%)$ & $19.3(36.5)$ & $21.0(33.7)$ \\
\hline$R_{\text {free }}^{b, c}(\%)$ & $26.4(37.6)$ & $28.6(37.8)$ \\
\hline root mean square (rms) bond length $(\AA)$ & 0.006 & 0.006 \\
\hline root mean square (rms) bond angle ( $\mathrm{deg}$ ) & 1.22 & 1.22 \\
\hline Ramachandran outliers (\%) & 0.16 & 0.21 \\
\hline
\end{tabular}

${ }^{a} R_{\text {sym }}=\sum\left|I_{i}-\langle I\rangle\right| / \sum I_{i}$, where $I_{i}$ is the intensity of $i^{\text {th }}$ observation and $\langle I\rangle$ is the mean intensity of the reflection. ${ }^{b}$ Values in parentheses are for reflections in the highest resolution shell. ${ }^{c} R_{\text {cryst }}=\sum\left|F_{\text {obs }}-F_{\text {calc }}\right| /$ $\sum\left|F_{\text {obs }}\right|$, where $F_{\text {obs }}$ and $F_{\text {calc }}$ are the observed and calculated structure factor amplitudes, respectively. $R_{\text {cryst }}$ and $R_{\text {free }}$ were calculated using the working and test sets, respectively.

refinement were performed with Refmac5. ${ }^{31}$ PISA server was used to analyze the oligomeric organization of the protein and the molecular interface area. ${ }^{32}$ Figures were drawn with UCSF Chimera. ${ }^{33}$ The detailed data processing statistics of the collected data set are summarized in Table 1.

\section{RESULTS}

Expression and Purification of PcAOX Wild-Type and Variants. The production of soluble PcAOX, which is a fungal protein, was facilitated by codon optimization for $E$. coli expression and presumably also by the fusion to a small ubiquitin-related modifier (SUMO) at the N-terminus of the protein. The SUMO fusion is known to enhance the expression level and solubility of partially insoluble proteins, which were often encountered with enzymes of eukaryotic origin that are expressed in E. coli. ${ }^{19}$ From $1 \mathrm{~L}$ of culture, $\sim 600$ $\mathrm{mg}$ of purified yellow-colored His-SUMO-PcAOX could be obtained after one step of purification. The purified PcAOX generally displayed a typical UV-vis absorption spectrum for enzymes containing flavin in the oxidized state (quinone), with two absorption maxima at 385 and $455 \mathrm{~nm}$ (Figure 1A). Upon unfolding the enzyme with $0.1 \%(\mathrm{w} / \mathrm{v})$ SDS, the absorption spectrum of the released flavin was recorded and used to determine the extinction coefficient of the enzyme $\left(\varepsilon_{455}=10.3\right.$ $\left.\mathrm{mM}^{-1} \mathrm{~cm}^{-1}\right)$. Very occasionally, purified PcAOX contained a variable amount of flavin cofactor in the semiquinone state. Evidence for this came from the observation of higher absorbance at $385 \mathrm{~nm}$ than at $455 \mathrm{~nm}$ and the presence of 


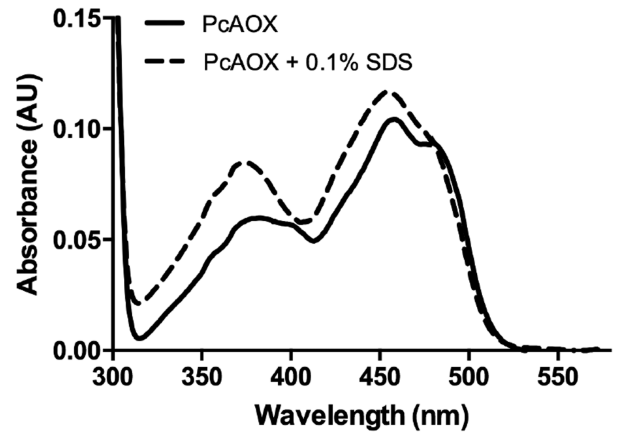

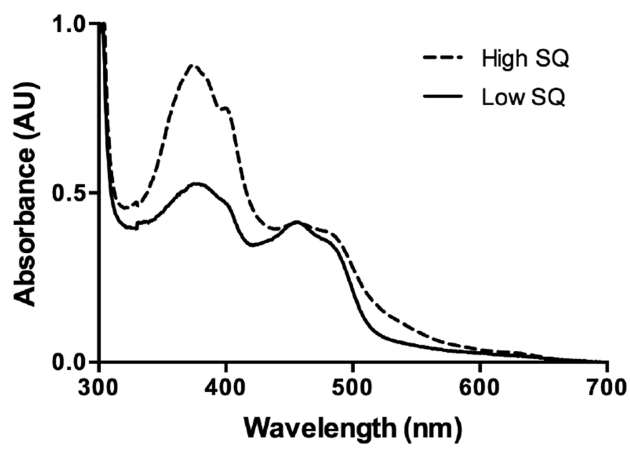

B

Figure 1. UV-vis spectral properties of PcAOX. (A) Absorption spectra of His-SUMO-PcAOX in $50 \mathrm{mM}$ Tris-HCl pH 7.0 before (solid line) and after addition of $1 \%(\mathrm{w} / \mathrm{v})$ SDS (broken line). (B) Spectra for F101S PcAOX. Comparison of the absorption spectra observed after two purification processes. Different ratios of the semiquinone (SQ) and quinone forms of the flavin are observed.

an additional shoulder at $400 \mathrm{~nm}$ (Figure 1B). ${ }^{34}$ These protein batches were not used for kinetic studies.

The N-terminal His-SUMO tag was cleaved from the fusion enzyme by treatment with SUMO protease. The UV-vis absorption spectrum of the resulting PcAOX was identical to that of the fusion enzyme. The observed catalytic rates measured with ethanol were also comparable for both forms (tagged and untagged) of PcAOX $\left(\sim 15 \mathrm{~s}^{-1}\right.$ at $125 \mathrm{mM}$ ethanol). These results indicated that the SUMO fusion at the $\mathrm{N}$-terminus has no significant effects either on the microenvironment around the flavin cofactor or the enzyme activity. Nevertheless, the native PcAOX had the tendency to precipitate upon storage at $4{ }^{\circ} \mathrm{C}$, implying that the HisSUMO fusion is crucial for maintaining the protein stability. For this reason, except for the crystallization and structure determination, we used His-SUMO-PcAOX (wild-type or mutant) for all kinetics and substrate profiling experiments.

pH Optimum and Thermostability of PcAOX. To evaluate the optimal $\mathrm{pH}$ for wild-type PcAOX activity, methanol oxidation rates were measured between $\mathrm{pH} 3.0-$ 10. The enzyme displayed a clear preference for neutral to basic conditions (Figure 2), with an optimal $\mathrm{pH}$ value of 9.0. The oxidase retained more than $75 \%$ of its activity between $\mathrm{pH}$ 7.0 and $\mathrm{pH}$ 10.0. Beyond $\mathrm{pH} 6.0$ and $\mathrm{pH} 11.0$, the activity sharply decreased below $50 \%$ of that at $\mathrm{pH} 9.0$.

The melting temperatures $\left(T_{\mathrm{m}}\right)$ of wild-type PcAOX determined by the ThermoFAD method in various buffers indicated that the enzyme is highly thermostable (Table 2).

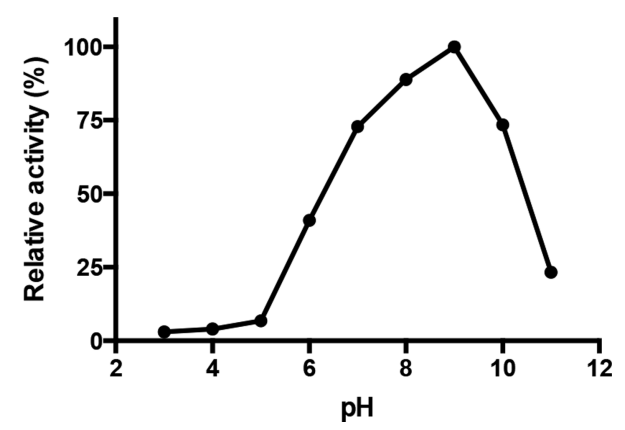

Figure 2. Effect of $\mathrm{pH}$ on methanol oxidation catalyzed by wild-type PcAOX. The reactions contained $40 \mathrm{mM}$ Britton-Robinson buffer, $0.1 \mu \mathrm{M}$ PcAOX, and $25 \mathrm{mM}$ methanol. Activity was monitored, by following dioxygen consumption for $5 \mathrm{~min}$ at $23{ }^{\circ} \mathrm{C}$, using a Hansatech Oxygraph instrument.
Table 2. Unfolding Temperatures of PcAOXs in Different Buffers Determined by the ThermoFAD Method

\begin{tabular}{lccc} 
& \multicolumn{3}{c}{$T_{\mathrm{m}}\left({ }^{\circ} \mathrm{C}\right)$ of PcAOX } \\
\cline { 3 - 5 } condition & wild-type & F101S & F101N \\
\hline 5 mM KPi pH 7.5 & 58 & 51 & 52 \\
$50 \mathrm{mM} \mathrm{KPi} \mathrm{pH} \mathrm{7.5}$ & 57 & 49 & 50 \\
$50 \mathrm{mM}$ Tris-HCl pH 7.5 & 58 & 51 & 53 \\
$50 \mathrm{mM} \mathrm{HEPES} \mathrm{pH} \mathrm{7.5}$ & 61 & 52 & 53 \\
Britton-Robinson buffer, pH 3.0 & 31 & 36 & 37 \\
Britton-Robinson buffer, pH 4.0 & 47 & 46 & 48 \\
Britton-Robinson buffer, pH 5.0 & 62 & 50 & 48 \\
Britton-Robinson buffer, pH 6.0 & 62 & 51 & 55 \\
Britton-Robinson buffer, pH 7.0 & 57 & 51 & 53 \\
Britton-Robinson buffer, pH 8.0 & 53 & 48 & 50 \\
Britton-Robinson buffer, pH 9.0 & 43 & 41 & 42 \\
Britton-Robinson buffer, pH 10.0 & 35 & 34 & 34 \\
Britton-Robinson buffer, pH 11.0 & 31 & 30 & 31 \\
100 mM NaCl, 50 mM KPi, pH 7.5 & 56 & 50 & 52 \\
$500 \mathrm{mM} \mathrm{NaCl,} \mathrm{50} \mathrm{mM} \mathrm{KPi,} \mathrm{pH} \mathrm{7.5}$ & 55 & 50 & 52 \\
1 M glycerol, 50 mM KPi, pH 7.5 & 58 & 57 & 55 \\
5 M glycerol, 50 mM KPi, pH 7.5 & 58 & 58 & 56 \\
20 mM MeOH, 50 mM KPi, pH 7.5 & 55 & 56 & 55 \\
$100 \mathrm{mM} \mathrm{MeOH,} \mathrm{50} \mathrm{mM} \mathrm{KPi,} \mathrm{pH} \mathrm{7.5}$ & 51 & 54 & 53 \\
$100 \mathrm{mM} \mathrm{EtOH,} \mathrm{50} \mathrm{mM} \mathrm{KPi,} \mathrm{pH} \mathrm{7.5}$ & 58 & 60 & 57 \\
$500 \mathrm{mM} \mathrm{EtOH,} \mathrm{50} \mathrm{mM} \mathrm{KPi,} \mathrm{pH} \mathrm{7.5}$ & 57 & 59 & 54 \\
\hline
\end{tabular}

Over a wide range of $\mathrm{pH}$ values from $\mathrm{pH} 5.0$ to $\mathrm{pH} 8.0, T_{\mathrm{m}}>$ $53{ }^{\circ} \mathrm{C}$, even though the enzyme is somewhat less thermostable at $\mathrm{pH} 4.0$ and $\mathrm{pH}$ 9.0. The addition of $\mathrm{NaCl}$ has virtually no effect on the enzyme thermostability, but we noticed that, in the absence of salt, concentrated enzyme had a tendency to precipitate at room temperature. The ThermoFAD experiments further suggested that PcAOX tolerates various watermiscible solvents such as methanol $(0.5 \mathrm{M})$, ethanol $(0.1 \mathrm{M})$, and glycerol $(5 \mathrm{M})$, as judged by their minor influence on the $T_{\mathrm{m}}$ values. Based on these experiments, a buffer consisting of $50 \mathrm{mM}$ potassium phosphate $(\mathrm{pH} 7.5)$ and a temperature of $25{ }^{\circ} \mathrm{C}$ were chosen as optimal conditions for activity assays.

Steady-State Kinetics. To determine the apparent steadystate kinetic parameters for PcAOX (see Table 3, as well as Figure S1 in the Supporting Information), a HRP-coupled assay was used to probe the $\mathrm{H}_{2} \mathrm{O}_{2}$ production rates upon oxidation of the different AOX substrates. The initial reaction rates were recorded and were satisfactory fitted to the Michaelis-Menten equation in all cases. The $k_{\text {cat }}$ values 
Table 3. Apparent Steady-State Kinetic Parameters for PcAOX ${ }^{a}$

\begin{tabular}{|c|c|c|c|c|c|c|c|c|c|c|c|c|}
\hline & \multicolumn{3}{|c|}{ wild-type } & \multicolumn{3}{|c|}{ F101S } & \multicolumn{3}{|c|}{ F101N } & \multicolumn{3}{|c|}{ M103S } \\
\hline & $K_{\mathrm{M}}$ & $k_{\text {cat }}$ & $k_{\mathrm{cat}} / K_{\mathrm{M}}$ & $K_{\mathrm{M}}$ & $k_{\text {cat }}$ & $k_{\text {cat }} / K_{\mathrm{M}}$ & $K_{\mathrm{M}}$ & $k_{\text {cat }}$ & $k_{\text {cat }} / K_{\mathrm{M}}$ & $K_{\mathrm{M}}$ & $k_{\text {cat }}$ & $k_{\text {cat }} / K_{\mathrm{M}}$ \\
\hline methanol & 2 & 18 & 9000 & 2 & 4 & 2000 & 14 & 10 & 710 & 2 & 1 & 500 \\
\hline ethanol & 15 & 19 & 1300 & 1 & 5 & 5000 & 11 & 10 & 910 & 1 & 1 & 1000 \\
\hline 1-propanol & 45 & 11 & 240 & 4 & 7 & 1800 & 11 & 12 & 1100 & 2 & 1 & 500 \\
\hline$(R)-(-)$-1,2-propanediol & $>1600$ & $>5$ & $>3$ & 110 & 4 & 36 & 1200 & 13 & 11 & 110 & 0.4 & 4 \\
\hline glycerol & $k_{\mathrm{obs}}=0$ & at 2 & substrate & 580 & 3 & 5 & $>2000$ & $>1$ & 1 & 650 & 0.4 & 1 \\
\hline
\end{tabular}

${ }^{a}$ Values obtained using the HRP-coupled assay in $50 \mathrm{mM}$ potassium phosphate, $\mathrm{pH}$ 7.5. $K_{\mathrm{M}}$ values are presented in units of mM, $k_{\text {cat }}$ values are presented in units of $\mathrm{s}^{-1}$, and $k_{\mathrm{cat}} / K_{\mathrm{M}}$ values are presented in units of $\mathrm{M}^{-1} \mathrm{~s}^{-1}$. Standard errors of best fits parameters determined by nonlinear regression are $\leq 11 \%$.
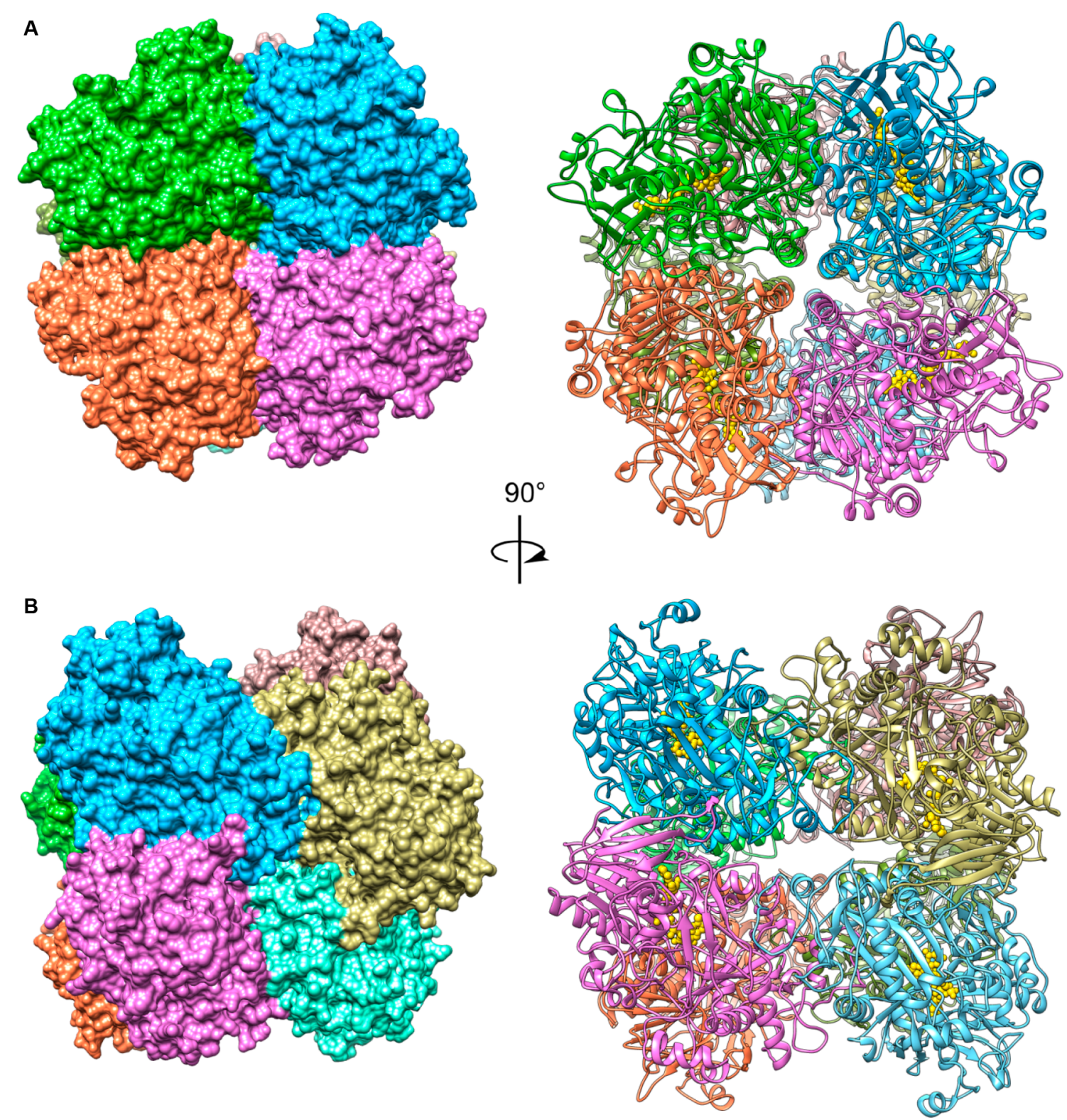

Figure 3. Crystal structure of PcAOX. The PcAOX octamer is shown as surface (left) and ribbon (right) representations with each individual monomer depicted in different color. For the sake of clarity, the FAD cofactor (in yellow ball-and-stick) is shown only for the monomers in the front. (A) Top view along the 4-fold axis. (B) Side view along the 2-fold axis (this orientation is obtained by rotating the oligomer $90^{\circ}$, with respect to the orientation in panel (A)).

measured with methanol and ethanol were found to be similar $\left(\sim 20 \mathrm{~s}^{-1}\right)$, whereas the $K_{\mathrm{M}}$ value for methanol was 8-fold lower than that for ethanol. Specifically, these determined $K_{M}$ values ( 2 and $15 \mathrm{mM}$, respectively) differ somewhat from previously reported (37 and $23 \mathrm{mM}$, respectively). ${ }^{17}$ Conversely, our measured $k_{\text {cat }}$ and $K_{\mathrm{M}}$ values are comparable to the kinetic parameters of PpAOX1 $\left(k_{\mathrm{cat}}\right.$ and $K_{\mathrm{M}}$ for methanol of $6 \mathrm{~s}^{-1}$ and $1 \mathrm{mM}$, respectively). ${ }^{15}$ Propanol turned out to be a good 
substrate for the enzyme, whereas virtually no activity was detected on 1,2-propanediol (see Table 2). Thus, as observed for other AOXs, methanol represents the best substrate for PcAOX and the activities rapidly vanish with alcohols of increasing lengths. Most importantly, for our goal of exploring PcAOX as a glycerol biocatalyst, we invariably observed only a very low activity using glycerol as a substrate. Only at extremely high substrate concentrations (1.0-4.0 M) we could measure some conversions with rates in the range of $0.1-0.2$ $\mathrm{s}^{-1}$ (see Table 3 ).

AOX Overall Structure. PcAOX crystallized as a homooctamer that, similarly to PpAOX1, can be interpreted as either a tetramer of dimers or a dimer of two tetramers facing each other (see Figures 3 and 4). Each monomer consists of residues 2 to 645 and a noncovalently bound FAD molecule. Within each monomer, two domains can be recognized with the classic topology found in the members of the GMC oxidoreductase superfamily: a substrate-binding domain and a FAD-binding domain (see Figure 4). ${ }^{35}$ The latter is characterized by the typical Rossmann fold, featuring a sandwich of a five-stranded parallel and a three-stranded antiparallel $\beta$-sheets. The substrate binding domain comprises a six-stranded $\beta$-antiparallel sheet. The interface between the two tetramers is quite extensive, as indicated by the burial of $11 \%\left(\sim 3000 \AA^{2}\right)$ of the monomer surface, including 38 intersubunit hydrogen bonds and 3 salt bridges. Therefore, upon octamer formation, each monomer buries $\sim 25 \%$ of its solvent-accessible surface area, which strongly stabilizes the oligomer (see Figure 3).

The monomers from PcAOX and PpAOX1 are closely related, as indicated by a root-mean-square ( $\mathrm{rms}$ ) deviation of $0.92 \AA$ for 642 common pairs of $\mathrm{C} \alpha$ atoms upon superposition of the monomer in the two enzyme structures (see Figure 4). The only major differences between the two structures entail a shorter loop (573-574, corresponding to 579-586 in PpAOX1) in the FAD-binding domain and a short insert (525-538, corresponding to 521-544 in PpAOX1) in the vicinity of the substrate-binding domain. The latter, so-called "enabling loop", facilitates formation of both dimeric and tetrameric subassemblies in PpAOX $1 .{ }^{15}$ In addition, PpAOX1 carries a peroxisomal targeting signal (PTS1) at the C-terminal extension, which was believed to be crucial for functional octamer assembly maturation. ${ }^{15}$ Interestingly, despite a high structural similarity, PcAOX does not contain the C-terminal signal involved in targeting yeast AOXs to peroxisomes.

The Active Site of PCAOX. Similar to the other GMC oxidases, ${ }^{16}$ all PcAOX subunits contain a dissociable and tightly bound FAD cofactor buried deep inside the FADbinding domain in an elongated shape (see Figures 4 and 5). This fact presumably prevents the release of the cofactor during catalysis. Similar to PpAOX1, the isoalloxazine ring in $\mathrm{PcAOX}$ is found in a bent conformation. A distinctive feature of PpAOX1 and other yeasts AOXs is the presence of a variable amount of modified FAD cofactor where the isoalloxazine ring is attached to an unusual arabityl instead of a ribityl chain (the carbon configuration of the sugar $\mathrm{C}^{\prime}$ is changed from $R$ to $S) .{ }^{15,36}$ In contrast, PcAOX does not harbor such modified flavin, probably because of interspecies variations and/or production and storage conditions. ${ }^{36}$

The substrate binding site in PcAOX is completely solventinaccessible, a remarkable feature that has been observed for PpAOX1 and also for members of the vanillyl alcohol oxidase family $^{37,38}$ (see Figure 5A). The two strictly conserved residues

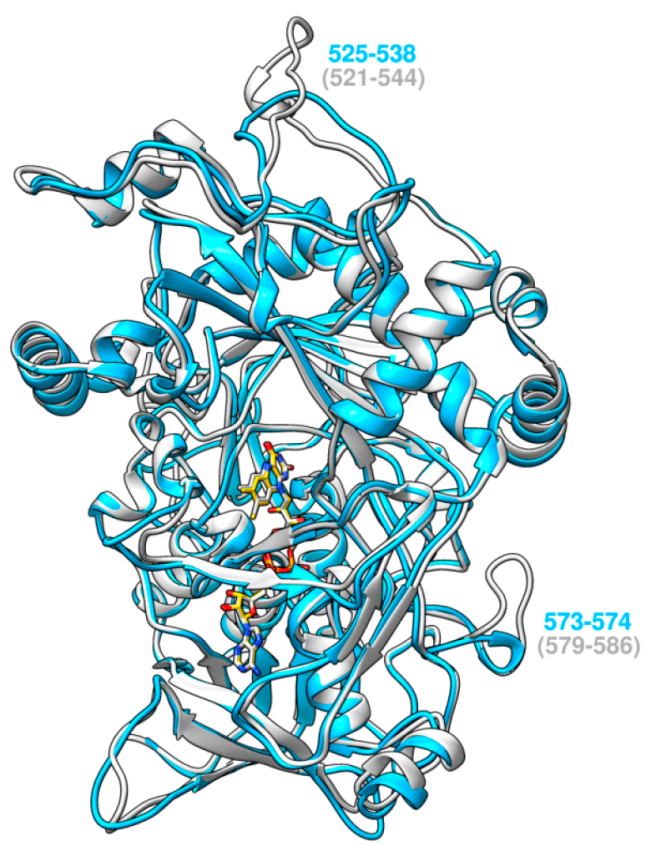

Figure 4. Superposition of PcAOX monomer A (in deep sky blue) with that of the homologous PpAOX1 (in light gray, 52\% sequence identity, PDB ID: 5HSA). The overall topology of the two structures and the active site are highly conserved. Besides a longer loop of 12 amino acids at the C-terminus in PpAOX1 (which is not visible in the figure due to the orientation), the major differences between the two proteins lie in the length of some loops that are labeled with the corresponding residues. $\mathrm{FAD}$ is drawn as sticks with $\mathrm{C}$ atoms in yellow (for PcAOX) or in light gray (for PpAOX1), O atoms in red, $\mathrm{N}$ atoms in blue, and $\mathrm{P}$ atoms in orange.

proximal to the isoalloxazine ring in all GMC oxidoreductases, His-His or His-Asn pairs, correspond to His561 and Asn604 in PcAOX (and to His567 and Asn616 in PpAOX1) (see Figure 5 and Figures $6 \mathrm{~A}$ and $6 \mathrm{~B}$ ). The active site histidine residue serves as a catalytic base in most of the GMC oxidoreductases, abstracting a proton from the substrate hydroxyl group, whereas the asparagine residue acts as a hydrogen donor. ${ }^{1,2}$

Comparative analyses of the two AOX structures showed that active site residues, most of which are either aromatic and/or hydrophobic, are largely conserved. Different amino acids between the two AOXs include Cys311, Phe313, His394, Phe402, and Phe419 in PpAOX1, which are replaced with Thre315, Leu317, Phe399, Tyr407, and Tyr419 in PcAOX, respectively (see Figure S2 in the Supporting Information). Despite these changes, the bulkiness and the hydrophobicity of the residues remains equivalent; hence, the size and the shape of the substrate cavity are essentially the same. Nevertheless, the replacement of Phe313 in PpAOX1 by Leu317 in PcAOX is noteworthy. As a result, the latter enzyme harbors some extra space for substrate binding (see Figures 6A and 6B). This may partly explain why PcAOX is able to convert glycerol (although with very poor efficiency), in contrast to PpAOX1.

Structure-Based Mutants Active on Glycerol. To probe the residues that might have a crucial role in defining substrate specificity, we modeled a glycerol molecule within the substrate binding pocket of PcAOX at the re side of the flavin cofactor. The cavity appears to have just about enough space to accommodate this polyol and allows for only a few hydrogen bonds, which may explain the very poor activity of PcAOX 


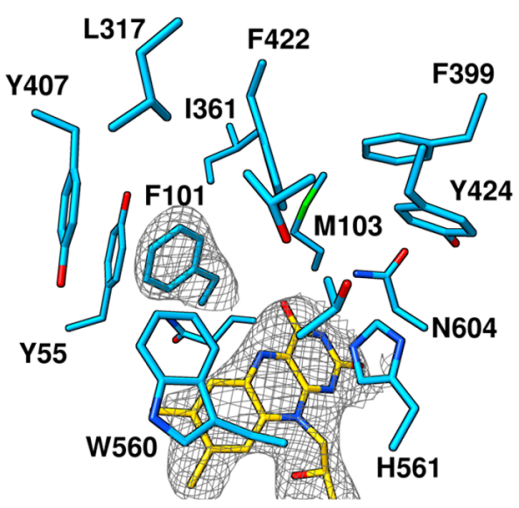

A

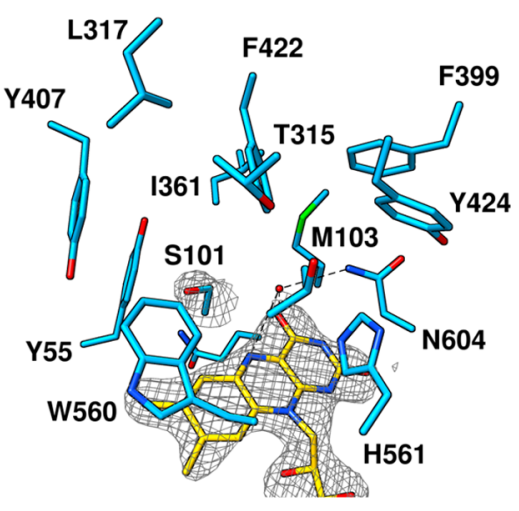

B

Figure 5. Quality of the electron density. Maps were calculated after molecular replacement and 8 -fold averaging and are contoured at $1.2 \sigma$ level. (A) The $2.6 \AA$ resolution map for Phe101 and the flavin in the wild-type structure. (B) The $2.5 \AA$ resolution map for the same protein region in the structure of the F101S mutant (see Table 1). For clarity, the labels for Gln102 and Thr559 are omitted.

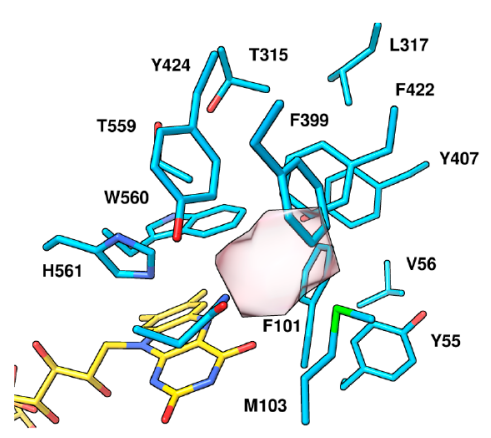

A

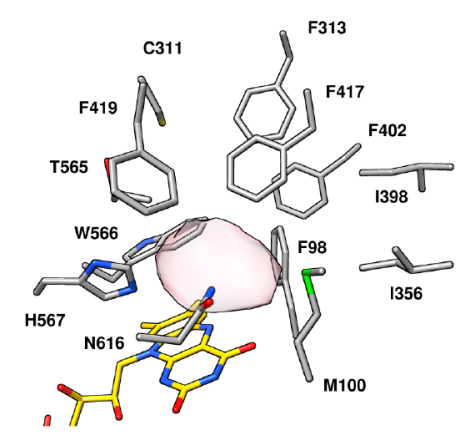

B

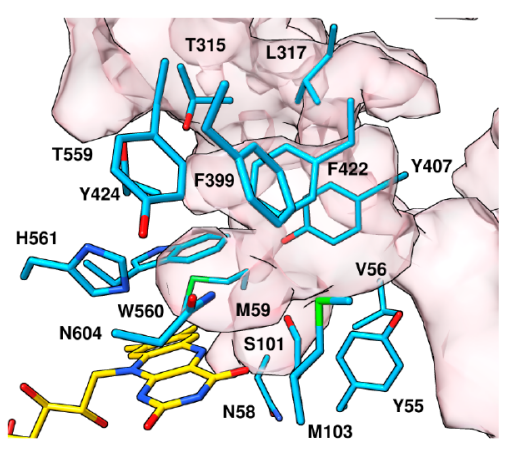

C

Figure 6. Active site. The three panels show the active-site cavities of (A) wild-type PcAOX, (B) PpAOX1, and (C) PcAOX F101S mutant. The structures are in the same orientation. Flavin carbons are shown in yellow, protein carbons are shown in gray, oxygens are shown in red, and nitrogens are shown in blue. The shape of the cavities is depicted as a pink semitransparent surface.

toward glycerol. In particular, residues Phe101 and Met103 were predicted to be in very close contact and, in the absence of conformational changes, with respect to the experimental structure, might clash with glycerol. We reason that a larger and more polar cavity could be created by mutating these residues into smaller side chains bearing $\mathrm{H}$-bonding groups. Therefore, we generated the mutants F101S, F101N, and M103S (see Table S1 in the Supporting Information).

In all cases, the expression yields of the mutants were the same as that of the wild-type PcAOX. Moreover, the generated mutants at position 101 had the same melting temperatures as the wild-type enzyme (see Table 2). Such an unperturbed thermostability was not to be taken for granted, because the mutations remove a hydrophobic residue deeply buried in the protein, which might cause some destabilization. In light of these very encouraging initial observations, the three F101S, F101N, and M103S variants were further characterized by performing steady-state kinetics with the same reference substrates used for the wild-type enzyme: methanol, ethanol, 1-propanol, (R)-(-)-1,2-propanediol, and glycerol (see Table 3 , as well as Figure S1 in the Supporting Information). These experiments nicely highlighted a clear trend in that the mutants feature higher catalytic efficiencies on ethanol (F101S, M103S) or propanol (F101N) rather than on methanol as found for the wild-type enzyme. The finding that all mutations increase the oxidation of $(R)-(-)-1,2$-propanediol was consistent with this trend. Most satisfactorily, the kinetic experiments indicated that the F101S and M103S variants oxidize glycerol much more efficiently than the wild-type enzyme to the extent that the steady-state kinetic parameters could be determined also for this substrate $\left(k_{\text {cat }}=0.4-3.0 \mathrm{~s}^{-1}, K_{\mathrm{M}}=0.58-0.65 \mathrm{M}\right)$; only M103S had low activity with $k_{\mathrm{obs}}<0.1 \mathrm{~s}^{-1}$ (see Table 3, as well as Figure S1). In particular, the F101S enzyme stood out as the most efficient catalyst for the oxidation of this polyol. Next, we confirmed glyceraldehyde production in the reactions of the F101S variant with glycerol by using the Purpald assay (see Figure 7). ${ }^{39}$ We also observed that the activity on glycerol is significantly decreased in the presence of $\mathrm{NaCl}$ (e.g., $40 \%$ relative activity with $25 \mathrm{mM} \mathrm{NaCl}$; see Figure 8A). Such inhibition effect was also observed with $\mathrm{MnCl}_{2}$ but not with $\mathrm{MnSO}_{4}$, suggesting that the chloride ion exerts a specific effect, possibly by competing with a dioxygen binding pocket. However, in the absence of $\mathrm{NaCl}$, the F101S mutant is stable for 2 days and exhibits $36 \%$ of the initial activity after 7 days (see Figure 8B). Therefore, the cavity-enlarging mutations resulted in the desired effect of increasing the activity on large substrates without decreasing expression yields and thermostability. Above all, F101S proved particularly effective in glycerol oxidation.

Given its properties, the X-ray structure of the F101S protein was determined by molecular replacement using the wild-type PcAOX structure as the search model (Figure 6C and Table 1). The overall structure and the active site of the mutant are highly similar to that of the wild-type enzyme. It can be deduced that the enhanced activity of the F101S mutant on glycerol is largely attributed to a more spacious binding site, 


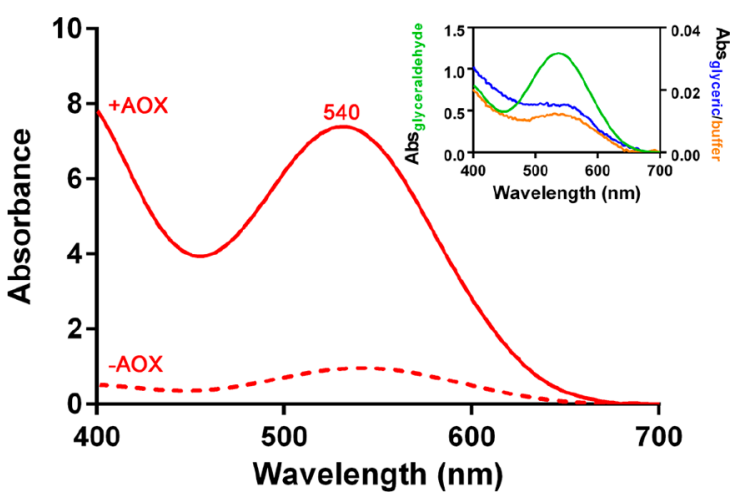

Figure 7. Determination of aldehyde production in the reactions of F101S AOX with glycerol using the Purpald assay. All spectra showed here correspond to a 5-fold dilution of the initial reaction or standard solutions (before mixing with Purpald). When additional dilutions were required (see the Materials and Methods section), the spectra were corrected to obtain those presented here. $205 \mathrm{mM}$ glycerol was incubated in the presence $(13 \mu \mathrm{M})$ and the absence of F101S AOX (as represented by the red solid line and the red broken line, respectively). The inset shows that buffer (orange line) and $0.2 \mathrm{mM}$ glyceric acid (blue line) exhibited very low absorbance at $540 \mathrm{~nm}$, compared to that observed for $0.2 \mathrm{mM}$ glyceraldehyde (green line), after incubating with Purpald (standard solutions without AOX).

together with the hydrogen bonding that may occur between the Ser at position 101 and glycerol. Indeed, inspection of the active site by the program VOIDOO ${ }^{40}$ allows one to identify a cavity in front of the flavin cofactor which features a different shape and volume in the wild-type and the F101S PcAOX structures (see Figures $6 \mathrm{~A}$ and $6 \mathrm{C}$ ). The cavity in the mutant F101S has a substantially larger volume $\left(127 \AA^{3}\right)$, compared to that of the wild-type PcAOX and the PpAOX1 (37 and $31 \AA^{3}$, respectively). Moreover, the cavity in the mutant opens up to the surface of the protein connecting to the interface with the adjacent subunit, which may represent the pathway where substrates enter the active site (Figure 6C).

\section{DISCUSSION}

With the rapid increase in biodiesel production and the massive availability of its byproduct glycerol, effective (bio)catalysts that can convert glycerol to value-added products are in demand. ${ }^{41-43}$ Among these, flavin-dependent oxidases that can oxidize glycerol are highly desirable, as such biocatalysts that have the potential to produce enantiomerically pure glyceraldehyde or glyceric acid. Thus, an efficient glycerol oxidase would allow conversion of glycerol to valuable building blocks while the concomitantly produced $\mathrm{H}_{2} \mathrm{O}_{2}$ may also be of value. Attempts to engineer the available alcohol/polyol oxidases, e.g., alditol oxidase, into a "glycerol oxidase" by directed evolution and rational design have resulted in ineffective glycerol oxidases with poor catalytic efficiencies. The best alditol oxidase mutant for oxidation of glycerol was found to display a $k_{\text {cat }}$ value of only $0.06 \mathrm{~s}^{-1}$. ${ }^{44}$

The recent identification of a novel AOX from the white-rot basidiomycete $P$. chrysosporium that was suggested to possess minimal yet significant glycerol oxidase activity prompted us to further investigate this enzyme. Expression of aox-encoding genes in prokaryotic hosts is a challenge, since most of AOXs are of eukaryotic origin. However, we were able to overexpress PcAOX in E. coli. In fact, AOX from $P$. chrysosporium represents the first fungal methanol oxidase within the GMC superfamily that can be heterologously expressed in E. coli with a rather impressive high yield: $>600 \mathrm{mg}$ of pure protein from 1 $\mathrm{L}$ of culture can be obtained by merely one purification step. We observed that the purified PcAOX prefers neutral or basic conditions and is active on methanol and ethanol with similarly high catalytic efficiencies. The steady-state kinetic parameters reported here for PcAOX deviate somewhat from those previously reported by Linke et al., ${ }^{17}$ which may be due to differences in reaction and/or production conditions. Also note that isolation of PcAOX from the natural host was shown to be problematic: it could only be isolated by a gel permeation step while any other purification attempt resulted in inactivation. ${ }^{17}$ The presence of a varying amount of modified $\mathrm{FAD}$ and/or the semiquinone flavin form may also have an influence on the catalytic properties observed for PcAOX obtained in laboratories using a different expression system and conditions. Indeed, it was previously shown that the modified FAD confers the AOXs a higher affinity for methanol and a lower maximum activity. ${ }^{36,45}$ The presence of a noncatalytically relevant stable flavin semiquinone has been previously reported for AOXs from diverse sources, ${ }^{10,46,47}$ as well as for other flavin-dependent oxidases such as monoamine oxidase B, vanillyl alcohol oxidase, and choline oxidase. ${ }^{48-50}$ The reason for this observation is still unknown.

Given the objective of our studies, the very low activity toward glycerol by wild-type PcAOX $\left(k_{\mathrm{obs}}=0.2 \mathrm{~s}^{-1}\right.$ at $2 \mathrm{M}$ glycerol) was rather disappointing. This activity is simply too low to be relevant for physiological conditions or industrial applications. Inspection of PcAOX's crystal structure reveals

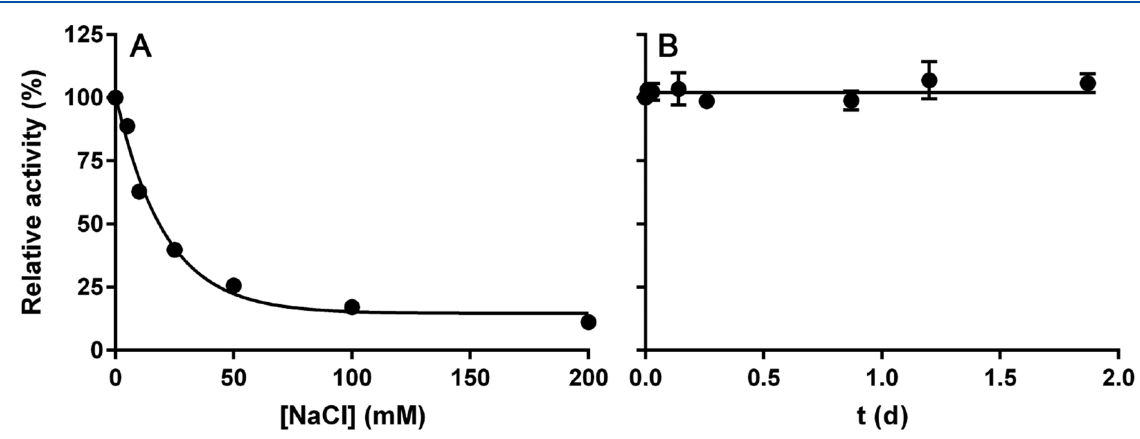

Figure 8. Activity on glycerol for the F101S PcAOX variant (A) in the presence of $\mathrm{NaCl}$ and (B) during incubation for prolonged time. In panel $(\mathrm{A})$, enzyme $(1 \mu \mathrm{M})$ activity on glycerol $(2 \mathrm{M})$ was determined using the HRP-coupled assay in $100 \mathrm{mM}$ potassium phosphate $\mathrm{pH} 7.5$ with various $\mathrm{NaCl}$ concentrations. In panel (B), the long-term stability for the F101S PcAOX variant was probed by incubating the enzyme (32 $\mu \mathrm{M})$ in $100 \mathrm{mM}$ potassium phosphate $\left(\mathrm{pH} 7.5\right.$ and $\left.25^{\circ} \mathrm{C}\right)$. Activity on glycerol $(2 \mathrm{M})$ was determined using the HRP-coupled assay at various time points. 
that the substrate-binding is a small and remarkably solventinaccessible cavity, in good agreement with a clear preference for methanol as the best substrate. Modeling a glycerol molecule into the active site (Figure 6A) invariably showed that the cavity has just about enough space to accommodate this polyol. Moreover, the high hydrophobicity of the substrate binding pocket allows limited hydrogen bonding interactions between glycerol and PcAOX. Based on the data, we designed mutants that turned out to exhibit the desired significant improvement on glycerol conversion without loss in thermostability and protein expression yields. We consider the development of these PcAOX variants (especially the F101S enzyme) as a very promising result because it delivers a first biocatalyst for polyol conversions useful as a template for further scale-up development and improvement. The mutants with significant activity on glycerol can serve as biocatalysts for producing glyceraldehyde or for the generation of hydrogen peroxide. Glyceraldehyde is seen as a precursor for various high-value products. ${ }^{51}$ Enzyme-catalyzed formation of hydrogen peroxide using an inexpensive and renewable substrate is also highly attractive to support biocatalysts that require hydrogen peroxide, such as peroxidases and peroxygenases, or can serve as a chemical oxidant. Furthermore, the generated mutant enzymes also accept other small aliphatic alcohols such as (R)-(-)-1,2-propanediol, yielding the corresponding lactaldehyde. Altogether, the generated PcAOX variants provide a new biocatalytic toolbox of alcohol oxidases.

\section{ASSOCIATED CONTENT}

\section{S Supporting Information}

The Supporting Information is available free of charge on the ACS Publications website at DOI: 10.1021/acs.biochem.8b00918.

Oxidation rates as a function of alcohol concentrations to determine the apparent steady-state kinetic parameters shown in Table 2 (Figure S1); multiple sequence alignment of PcAOX and AOX from Gloeophyllum trabeum (GtAOX), Pichia pastoris (PpAOX), and Candida boidinii (CbAOX) (GenBank: HG425201.1, $\mathrm{ABI} 14440.1$, AAB57849.1, and AAA34321.1, respectively) (Figure S2); list of primers used in this study (Table S1) (PDF)

\section{AUTHOR INFORMATION}

\section{Corresponding Authors}

*Tel.: +39 0382985525. E-mail: andrea.mattevi@unipv.it (A. Mattevi).

*Tel.: (+31) 5036 34345. E-mail: m.w.fraaije@rug.nl (M. W. Fraaije).

ORCID $\odot$

Claudia Binda: 0000-0003-2038-9845

Andrea Mattevi: 0000-0002-9523-7128

Marco W. Fraaije: 0000-0001-6346-5014

Present Address

${ }^{\#}$ CarbExplore Research, Zernikepark 12, 9747 AN Groningen, The Netherlands.

\section{Notes}

The authors declare no competing financial interest.

\section{ACKNOWLEDGMENTS}

This research was supported by the European Union (EU) project ROBOX (Grant Agreement No. 635734) under EU's Horizon 2020 Programme Research and Innovation actions (No. H2020-LEIT BIO-2014-1). Any statement made herein reflects only the views of the authors. The European Union is not liable for any use that may be made of the information contained herein. We thank the European Synchrotron Radiation Facility (ESRF) and the Swiss Light Source (SLS) for providing beamtime and assistance. F. Forneris, S. Rovida, S. Savino, A. Giusti, and S. Rosarin are acknowledged for their experimental supports.

\section{ABBREVIATIONS}

AOX, alcohol oxidase; GMC, glucose-methanol-choline; HRP, horseradish peroxidase; SUMO, small ubiquitin-related modifier

\section{REFERENCES}

(1) Dijkman, W. P., de Gonzalo, G., Mattevi, A., and Fraaije, M. W. (2013) Flavoprotein oxidases: Classification and applications. Appl. Microbiol. Biotechnol. 97, 5177-5188.

(2) Romero, E., and Gadda, G. (2014) Alcohol oxidation by flavoenzymes. Biomol. Concepts 5, 299-318.

(3) Hollmann, F., Arends, I. W., Buehler, K., Schallmey, A., and Bühler, B. (2011) Enzyme-mediated oxidations for the chemist. Green Chem. 13, 226-265.

(4) Pickl, M., Fuchs, M., Glueck, S. M., and Faber, K. (2015) The substrate tolerance of alcohol oxidases. Appl. Microbiol. Biotechnol. 99, 6617-6642.

(5) Romano, D., Villa, R., and Molinari, F. (2012) Preparative biotransformations: Oxidation of alcohols. ChemCatChem 4, 739749 .

(6) Bankar, S. B., Bule, M. V., Singhal, R. S., and Ananthanarayan, L. (2009) Glucose oxidase-an overview. Biotechnol. Adv. 27, 489-501.

(7) Pollegioni, L., Molla, G., Sacchi, S., Rosini, E., Verga, R., and Pilone, M. S. (2008) Properties and applications of microbial D-amino acid oxidases: Current state and perspectives. Appl. Microbiol. Biotechnol. 78, 1-16.

(8) Turner, N. J. (2011) Enantioselective oxidation of C-O and C$\mathrm{N}$ bonds using oxidases. Chem. Rev. 111, 4073-4087.

(9) Pollegioni, L., Piubelli, L., and Molla, G. (2009) Cholesterol oxidase: Biotechnological applications. FEBS J. 276, 6857-6870.

(10) Bringer, S., Sprey, B., and Sahm, H. (1979) Purification and properties of alcohol oxidase from Poria contigua. Eur. J. Biochem. 101, 563-570.

(11) Kato, N., Omori, Y., Tani, Y., and Ogata, K. (1976) Alcohol oxidases of Kloeckera sp. and Hansenula polymorpha. Eur. J. Biochem. 64, 341-350.

(12) Vonck, J., and van Bruggen, E. F. (1992) Determination of the molecular packing of three-dimensional crystals of alcohol oxidase from Pichia pastoris by electron microscopy and image analysis. $J$. Struct. Biol. 109, 78-85.

(13) van der Klei, I. J., Harder, W., and Veenhuis, M. (1991) Biosynthesis and assembly of alcohol oxidase, a peroxisomal matrix protein in methylotrophic yeasts: A review. Yeast 7, 195-209.

(14) Daniel, G., Volc, J., Filonova, L., Plihal, O., Kubatova, E., and Halada, P. (2007) Characteristics of Gloeophyllum trabeum alcohol oxidase, an extracellular source of $\mathrm{H}_{2} \mathrm{O}_{2}$ in brown rot decay of wood. Appl. Environ. Microbiol. 73, 6241-6253.

(15) Koch, C., Neumann, P., Valerius, O., Feussner, I., and Ficner, R. (2016) Crystal structure of alcohol oxidase from Pichia pastoris. PLoS One 11, e0149846.

(16) Vonck, J., Parcej, D. N., and Mills, D. J. (2016) Structure of alcohol oxidase from Pichia pastoris by cryo-electron microscopy. PLoS One 11, e0159476. 
(17) Linke, D., Lehnert, N., Nimtz, M., and Berger, R. G. (2014) An alcohol oxidase of Phanerochaete chrysosporium with a distinct glycerol oxidase activity. Enzyme Microb. Technol. 61-62, 7-12.

(18) Waterham, H. R., Russell, K. A., Vries, Y., and Cregg, J. M. (1997) Peroxisomal targeting, import, and assembly of alcohol oxidase in Pichia pastoris. J. Cell Biol. 139, 1419-1431.

(19) Malakhov, M. P., Mattern, M. R., Malakhova, O. A., Drinker, M., Weeks, S. D., and Butt, T. R. (2004) SUMO fusions and SUMOspecific protease for efficient expression and purification of proteins. $J$. Struct. Funct. Genomics 5, 75-86.

(20) Macheroux, P. (1999) UV-visible spectroscopy as a tool to study flavoproteins. Flavoprotein protocols 131, 1-7.

(21) Britton, H. T. S., and Robinson, R. A. (1931) CXCVIII.universal buffer solutions and the dissociation constant of veronal. $J$. Chem. Soc. 0, 1456-1462.

(22) Forneris, F., Orru, R., Bonivento, D., Chiarelli, L. R., and Mattevi, A. (2009) ThermoFAD, a thermofluor-adapted flavin ad hoc detection system for protein folding and ligand binding. FEBS J. 276, 2833-2840.

(23) Federico, R., Angelini, R., Ercolini, L., Venturini, G., Mattevi, A., and Ascenzi, P. (1997) Competitive inhibition of swine kidney copper amine oxidase by drugs: Amiloride, clonidine, and gabexate mesylate. Biochem. Biophys. Res. Commun. 240, 150-152.

(24) Kabsch, W. (2010) Xds. Acta Crystallogr., Sect. D: Biol. Crystallogr. 66, 125-132.

(25) Kabsch, W. (2010) Integration, scaling, space-group assignment and post-refinement. Acta Crystallogr., Sect. D: Biol. Crystallogr. 66, 133-144.

(26) Winn, M. D., Ballard, C. C., Cowtan, K. D., Dodson, E. J., Emsley, P., Evans, P. R., Keegan, R. M., Krissinel, E. B., Leslie, A. G., McCoy, A., McNicholas, S. J., Murshudov, G. N., Pannu, N. S., Potterton, E. A., Powell, H. R., Read, R. J., Vagin, A., and Wilson, K. S. (2011) Overview of the CCP4 suite and current developments. Acta Crystallogr., Sect. D: Biol. Crystallogr. 67, 235-242.

(27) Lang, P. T., Holton, J. M., Fraser, J. S., and Alber, T. (2014) Protein structural ensembles are revealed by redefining X-ray electron density noise. Proc. Natl. Acad. Sci. U. S. A. 111, 237-242.

(28) Karplus, P. A., and Diederichs, K. (2015) Assessing and maximizing data quality in macromolecular crystallography. Curr. Opin. Struct. Biol. 34, 60-68.

(29) McCoy, A. J., Grosse-Kunstleve, R. W., Adams, P. D., Winn, M. D., Storoni, L. C., and Read, R. J. (2007) Phaser crystallographic software. J. Appl. Crystallogr. 40, 658-674.

(30) Emsley, P., and Cowtan, K. (2004) Coot: Model-building tools for molecular graphics. Acta Crystallogr., Sect. D: Biol. Crystallogr. 60, $2126-2132$.

(31) Murshudov, G. N., Vagin, A. A., and Dodson, E. J. (1997) Refinement of macromolecular structures by the maximum-likelihood method. Acta Crystallogr., Sect. D: Biol. Crystallogr. 53, 240-255.

(32) Krissinel, E., and Henrick, K. (2007) Inference of macromolecular assemblies from crystalline state. J. Mol. Biol. 372, 774-797.

(33) Pettersen, E. F., Goddard, T. D., Huang, C. C., Couch, G. S., Greenblatt, D. M., Meng, E. C., and Ferrin, T. E. (2004) UCSF Chimera- a visualization system for exploratory research and analysis. J. Comput. Chem. 25, 1605-1612.

(34) Massey, V., and Hemmerich, P. (1980) Active-site probes of flavoproteins. Biochem. Soc. Trans. 8, 246-257.

(35) Fraaije, M. W., and Mattevi, A. (2000) Flavoenzymes: Diverse catalysts with recurrent features. Trends Biochem. Sci. 25, 126-132.

(36) Bystrykh, L. V., Dijkhuizen, L., and Harder, W. (1991) Modification of flavin adenine dinucleotide in alcohol oxidase of the yeast Hansenula polymorpha. J. Gen. Microbiol. 137, 2381-2386.

(37) Mattevi, A., Fraaije, M. W., Mozzarelli, A., Olivi, L., Coda, A., and van Berkel, W. J. (1997) Crystal structures and inhibitor binding in the octameric flavoenzyme vanillyl-alcohol oxidase: The shape of the active-site cavity controls substrate specificity. Structure 5, 907920.

(38) Nguyen, Q.-T., de Gonzalo, G., Binda, C., Rioz-Martínez, A., Mattevi, A., and Fraaije, M. W. (2016) Biocatalytic properties and structural analysis of eugenol oxidase from Rhodococcus jostii RHA1: A versatile oxidative biocatalyst. ChemBioChem 17, 1359-1366.

(39) Anthon, G. E., and Barrett, D. M. (2004) Comparison of three colorimetric reagents in the determinationof methanol with alcohol oxidase. application to the assay of pectin methylesterase. J. Agric. Food Chem. 52, 3749-3753.

(40) Kleywegt, G. J., and Jones, T. A. (1994) Detection, delineation, measurement and display of cavities in macromolecular structures. Acta Crystallogr., Sect. D: Biol. Crystallogr. 50, 178-185.

(41) Johnson, D. T., and Taconi, K. A. (2007) The glycerin glut: Options for the value-added conversion of crude glycerol resulting from biodiesel production. Environ. Prog. 26, 338-348.

(42) Pagliaro, M., Ciriminna, R., Kimura, H., Rossi, M., and Della Pina, C. (2007) From glycerol to value-added products. Angew. Chem., Int. Ed. 46, 4434-4440.

(43) Zhou, C. C., Beltramini, J. N., Fan, Y., and Lu, G. M. (2008) Chemoselective catalytic conversion of glycerol as a biorenewable source to valuable commodity chemicals. Chem. Soc. Rev. 37, 527549.

(44) Gerstenbruch, S., Wulf, H., Mußmann, N., O'Connell, T., Maurer, K., and Bornscheuer, U. T. (2012) Asymmetric synthesis of D-glyceric acid by an alditol oxidase and directed evolution for enhanced oxidative activity towards glycerol. Appl. Microbiol. Biotechnol. 96, 1243-1252.

(45) van Berkel, W. J., Eppink, M. H., and Schreuder, H. A. (1994) Crystal structure of $p$-hydroxybenzoate hydroxylase reconstituted with the modified $\mathrm{FAD}$ present in alcohol oxidase from methylotrophic yeasts: Evidence for an arabinoflavin. Protein Sci. 3, 2245-2253.

(46) Geissler, J., and Hemmerich, P. (1981) Yeast methanol oxidases: An unusual type of flavoprotein. FEBS Lett. 126, 152-156.

(47) Mincey, T., Tayrien, G., Mildvan, A. S., and Abeles, R. H. (1980) Presence of a flavin semiquinone in methanol oxidase. Proc. Natl. Acad. Sci. U. S. A. 77, 7099-7101.

(48) DeRose, V. J., Woo, J. C., Hawe, W. P., Hoffman, B. M., Silverman, R. B., and Yelekci, K. (1996) Observation of a flavin semiquinone in the resting state of monoamine oxidase $\mathrm{B}$ by electron paramagnetic resonance and electron nuclear double resonance spectroscopy. Biochemistry 35, 11085-11091.

(49) Gygli, G., and van Berkel, W. J. H. (2017) Communication. vanillyl alcohol oxidases produced in Komagataella phaffii contain a highly stable noncovalently bound anionic FAD semiquinone. Biocatalysis 3, 17-26.

(50) Ghanem, M., Fan, F., Francis, K., and Gadda, G. (2003) Spectroscopic and kinetic properties of recombinant choline oxidase from Arthrobacter globiformis. Biochemistry 42, 15179-15188.

(51) Dodekatos, G., Schünemann, S., and Tüysüz, H. (2018) Recent advances in thermo-, photo-, and electro-catalytic glycerol oxidation. ACS Catal. 8, 6301-6333. 